доктор педагогічних наук, проректор з науково-методичної роботи (комунальний заклад "Житомирський обласний інститут післядипломної педагогічної освіти" Житомирської обласної ради) al.pastov@gmail.com ORCID : $\odot 00 \odot-0002-6450-\odot 843$

\title{
ОСОБЛИВОСТІ РЕАЛІЗАЦІЇ МЕТОДІВ УПРАВЛІННЯ ОСВІТОЮ В УМОВАХ РОЗВИТКУ ОСВITHIX СИСТЕМ
}

У статті досліджено особливості реалізації методів управління освітою в умовах розвитку освітніх систем. Зроблено висновок, що в прочесі еволюиії освітніх систем від жорсткої до системи з делегованими управлінськими повноваженнями, "м'якої", з мережевою взаємодією і синергетичної особливостями реалізаиії методів управління є зростання громадської складової зазначених методів, конверсії домінантних методів управління в межах окремих груп та їхнє зміщення від організаційнорозпорядчих та економічних до психологічних і сочіальних.

Ключові слова: розвиток, освітня система, домінантні методи управління, громадська складова, конверсія, зміщення.

Постановка проблеми. В умовах нинішніх кардинальних суспільно-економічних перетворень в країні, динамічного реформування освітньої галузі нагальним $є$ впровадження демократичних моделей управління освітою, пошук та обгрунтування нових принципів, функцій, форм і методів управлінської діяльності. Водночас на сьогодні особливості реалізації методів управління в умовах трансформації освітніх систем досліджено недостатньо грунтовно.

Аналіз основних досліджень і публікацій. Перспективи та шляхи модернізації системи управління освітою в нових соціально-економічних умовах обгрунтовано в працях В. Андрущенка, В. Бондаря, М. Дарманського, Г. Єльникової, Л. Калініної, В. Кременя, В. Лугового, В. Маслова, Н. Ничкало, С. Ніколаєнка, В. Олійника, Н. Островерхової, В. Пікельної, О. Савченко та ін.

Метою статті $\epsilon$ проаналізувати особливості реалізації методів управління освітою в умовах розвитку освітніх систем.

Виклад основного матеріалу. У переважній більшості наукових праць під методами управління розуміються способи впливу керуючої підсистеми на керовану, що спрямовані на вирішення управлінських завдань і досягнення бажаних результатів. 3 позицій такого підходу методи управління розглядаються як статичні феномени і здебільшого аналізуються з позицій різноманітності їхніх класифікацій і змісту. Дослідники класифікують методи управління за масштабами застосування (загальні та особливі); за галузями та сферами застосування (управління бізнесом, промисловістю, освітою, охороною здоров'я та ін.); за роллю на різних етапах функціонування системи (методи дослідження організації, виведення іiі з кризи, стабілізувальні, розвивальні, ліквідаційні тощо); за ступенем опосередкованості впливу (прямі й непрямі); за рівнем узагальнення управлінських знань (методи теорії та практики управління); за управлінськими функціями (методи аналізу, планування, організації, контролю, коригування); за конкретними об'єктами управління (методи управління якістю, персоналом, проектами) тощо [1].

Зауважимо, що провести чітке розмежування різних методів управління в практичній діяльності важко - вони мають чимало спільних рис, часто застосовуються в комплексі, доповнюючи один одного, тощо. Водночас для кожної керуючої підсистеми завжди існують найбільш характерні й ефективні методи управління, які будемо називати домінантними.

Зазначимо, що в роботах різних науковців простежуються значні розбіжності як у класифікаціях, так і в змісті методів управління. Однак, на нашу думку, в умовах розвитку соціальних систем важливішим $\epsilon$ дослідження особливостей їхньої реалізації. Це стає тим більше очевидним, якщо під методами управління будемо розуміти способи взаємодії керуючої і керованої підсистем, спрямовані на вирішення управлінських завдань. Зрозуміло, що з посиленням демократизації суспільства і децентралізації влади змінюється характер таких взаємодій, що спричиняє трансформацію шляхів реалізації методів управління освітою.

Проаналізуємо детальніше ці процеси на прикладі методів управління, визначених за традиційною класифікацією, в якій виокремлюються такі методи, як організаційно-розпорядчі (організаційні, розпорядчі, дисциплінарні); психологічні (психологічні методи вивчення особистості, методи психологічного впливу, методи розроблення управлінських рішень); соціальні (методи соціального дослідження, планування, нормування, регулювання); економічні (програмно-цільовий метод бюджетного планування, методи економічного планування, фінансового стимулювання та ін.) $[1 ; 2 ; 3 ; 4]$. 
Нашими попередніми дослідженнями обгрунтовано, що в своєму розвитку ефективні освітні системи проходять фази від жорсткої до системи з делегованими управлінськими повноваженнями, "м'якої", 3 мережевою взаємодією, синергетичної системи, причому в жорсткій системі управління здійснюється лише керуючою підсистемою; у системі 3 делегованими повноваженнями частина управлінських повноважень делегується іншим підсистемам; у "м'якій" системі основні управлінські дії керуюча підсистема узгоджує з керуючими підсистемами нижчого рівня; у системі з мережевою взаємодією до прийняття управлінських рішень залучається широке коло зацікавлених структур; у синергетичній системі активну участь в управлінні беруть усі їі підсистеми [5]. Нами також установлено, що в процесі розвитку освітніх систем управлінський цикл у них еволюціонує від жорсткого до розгалуженого i мережевого, змінюючи свої атрибути від командних до консультативних, узгоджувальних та інтегрально-узгоджувальних [6].

У цій роботі ми обгрунтуємо, що в умовах розвитку освітніх систем особливостями реалізації методів управління ними є:

- зростання громадської складової зазначених методів;

- конверсія домінантних методів управління в межах окремих груп;

- зміщення домінантних методів управління освітою від організаційно-розпорядчих та економічних до психологічних і соціальних.

Розглянемо детальніше організаційно-розпорядчі методи управління освітою.

Як свідчить досвід, 3 розвитком демократичних процесів в освітніх системах зростає участь громадськості в розробленні, прийнятті й упровадженні довготривалих документів організаційного регламентування (законів, указів, постанов, положень, статутів тощо), розробці різноманітних актів організаційного нормування (нормативів навчального навантаження, норм витрат часу, чисельності педагогічного й обслуговуючого персоналу та ін.), організаційного інструктування (інструкцій, правил, вимог тощо) та організаційного інформування (актів, протоколів, доповідних записок, заяв та ін.), що дає змогу краще враховувати запити учасників освітнього процесу. У зв’язку з цим посилюється роль громадськості в процесах регламентування, нормування, інструктування освітньої діяльності, що свідчить про зростання громадської складової організаційних методів управління.

Крім того, як підтверджує практика, в умовах трансформації освітніх систем у групі організаційнорозпорядчих методів відбувається конверсія домінантних методів управління. Зокрема серед розпорядчих методів у жорсткій системі домінантними є накази, оперативні розпорядження, резолюції, приписи, інструктажі; у системі з делегованими управлінськими повноваженнями - рішення нарад при керівникові, затвердження рішень керівників структурних підрозділів, рекомендації за результатами консультацій і співбесід; у "м’якій" системі - рішення педагогічних (вчених) рад і конференцій, рекомендації круглих столів, тематичних дискусій, експертні оцінки; у системі з мережевою взаємодією - рішення конференцій колективу закладу та науково-практичних конференцій, висновки громадських експертиз, рекомендації інтернет-форумів 3 освітніх питань; у синергетичній системі - рішення загальних зборів колективу, рекомендації громадських слухань, громадські доручення, програмноцільові методи тощо.

Розглянутий нами варіант конверсії домінантних розпорядчих методів управління у різних фазах розвитку освітніх систем відображено в таблиці 1.

Зміни відбуваються також у групі дисциплінарних методів управління (зауваження, догани, переміщення посадових осіб, звільнення тощо), які реалізовуються в кожній наступній фазі розвитку освітніх систем 3 урахуванням позицій ширшого кола учасників освітнього процесу, що сприяє зростанню громадської складової зазначених методів. Причому з подальшим розвитком освітніх систем замість дисциплінарних методів управління починають домінувати такі психологічні методи як осуд, засудження, похвала, схвалення, комплімент, визнання тощо.

Аналогічні трансформації, як показує практичний досвід, відбуваються в розвинутих освітніх системах в процесі розв'язання складних завдань і прийняття важливих управлінських рішень, де все ширше використовуються такі психологічні методи, як метод "гарної ідеї", "мозкового штурму", Дельфі, щоденників, рольової гри, а також "мозкового штурму навпаки", синектики, "635", Дельбека, голосування "за-проти", утопічних ігор, Гордона, контрольних запитань, морфологічного аналізу, вільних асоціацій, "список атрибутів", матричних структур, "мрії про неможливе", параметричний аналіз, евристичний і науковий методи та ін. [3]. Це свідчить про те, що з розвитком освітніх систем у процесі вирішення управлінських завдань домінантні методи управління зазначеними системами зміщуються від організаційно-розпорядчих до психологічних. 
Домінантні розпорядчі методи управління в умовах трансформації освітніх систем

\begin{tabular}{|c|c|c|c|c|c|}
\hline 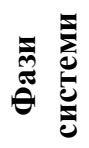 & $\begin{array}{c}\text { Жорстка } \\
\text { система }\end{array}$ & $\begin{array}{c}\text { Система } \\
\text { з делегованими } \\
\text { повноваженнями }\end{array}$ & $\begin{array}{l}\text { "М'яка" } \\
\text { система }\end{array}$ & $\begin{array}{c}\text { Система } \\
3 \text { мережевою } \\
\text { взасмодією }\end{array}$ & $\begin{array}{c}\text { Синергетична } \\
\text { система }\end{array}$ \\
\hline \multirow{4}{*}{ 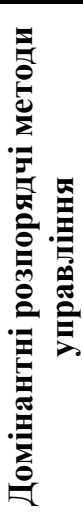 } & накази & $\begin{array}{l}\text { рішення нарад при } \\
\text { керівникові }\end{array}$ & $\begin{array}{l}\text { рішення } \\
\text { педагогічних } \\
\text { (вчених) рад }\end{array}$ & $\begin{array}{l}\text { рішення } \\
\text { конференцій } \\
\text { колективу }\end{array}$ & $\begin{array}{l}\text { рішення } \\
\text { загальних зборів } \\
\text { закладу }\end{array}$ \\
\hline & $\begin{array}{l}\text { оперативні } \\
\text { розпорядження } \\
\text { (доручення, } \\
\text { вказівки) }\end{array}$ & $\begin{array}{l}\text { затвердження } \\
\text { рішень керівників } \\
\text { структурних } \\
\text { підрозділів }\end{array}$ & $\begin{array}{l}\text { рекомендації } \\
\text { круглих столів, } \\
\text { тематичних } \\
\text { дискусій та ін. }\end{array}$ & $\begin{array}{l}\text { резолюції } \\
\text { науково- } \\
\text { практичних } \\
\text { конференцій } \\
\end{array}$ & $\begin{array}{l}\text { рекомендації } \\
\text { громадських } \\
\text { слухань } \\
\text { (обговорень) } \\
\end{array}$ \\
\hline & $\begin{array}{l}\text { резолюції, } \\
\text { приписи }\end{array}$ & $\begin{array}{l}\text { рекомендації за } \\
\text { результатами } \\
\text { консультацій }\end{array}$ & $\begin{array}{l}\text { резолюцї̈ } \\
\text { педагогічних } \\
\text { конференцій }\end{array}$ & $\begin{array}{l}\text { висновки } \\
\text { громадських } \\
\text { експертиз }\end{array}$ & $\begin{array}{l}\text { громадські } \\
\text { доручення }\end{array}$ \\
\hline & інструктажі & $\begin{array}{l}\text { пропозиції за } \\
\text { результатами } \\
\text { співбесід }\end{array}$ & $\begin{array}{l}\text { експертні } \\
\text { оцінки }\end{array}$ & $\begin{array}{l}\text { рекомендації } \\
\text { інтернет- } \\
\text { форумів }\end{array}$ & $\begin{array}{l}\text { програмно- } \\
\text { цільові методи }\end{array}$ \\
\hline
\end{tabular}

Зауважимо також, що в розвинених освітніх системах, як підтверджує досвід, розширюється використання психологічних методів вивчення особистості (самоспостереження, спостереження, опитування (бесіда, інтерв’ю, анкетування, тестування), експеримент (природний, лабораторний), вивчення документів (контент-аналіз, біографічний метод тощо)) [3]. Аналіз отриманих при цьому даних дає змогу суттєво підвищити ефективність психологічних методів управління, які спрямовані на гармонізацію стосунків працівників установ і закладів освіти й установлення в них сприятливого психологічного клімату, у тому числі на основі формування й розвитку малих груп, професійного відбору й навчання працівників, гуманізації праці та стосунків у трудовому колективі тощо.

Причому в умовах трансформації освітніх систем значно зростає громадська складова зазначених методів управління: у жорсткій системі вони реалізуються у більшості випадків лише з урахуванням позицій керівництва, у системі з делегованими управлінськими повноваженнями - за участі керівників підрозділів і лідерів соціальних підгруп, у "м'якій" системі - на основі узгодження їхніх позицій, у системі 3 мережевою взаємодією - 3 урахуванням думки всіх учасників освітнього процесу, у синергетичній системі - на основі узгодження їхніх позицій.

Крім того, зазначимо, що в умовах трансформацій освітніх систем від жорсткої до синергетичної відбувається конверсія прийомів і методів психологічного впливу - від вимоги, примушення та командування до прохання, переконання й підкріплення, поради, підтримки й похвали, спонукання, схвалення й навіювання, залучення, наслідування й зараження тощо.

Один 3 варіантів конверсії домінантних методів психологічного впливу в умовах трансформації освітніх систем наведено в таблиці 2.

3 розвитком освітніх систем, як свідчить практика, розширюється також застосування соціальних методів управління, що спрямовані на формування й розвиток освітянських колективів: методи соціального дослідження (соціометрія, групове оцінювання особистості, анкетування; інтерв'ю; спостереження; співбесіда та ін.), соціального планування, соціального нормування, соціального регулювання.

Причому в процесі еволюції освітніх систем помітно посилюється громадська складова зазначених методів. Активність освітян у таких напрямках діяльності як обмін досвідом, організація змагання, обговорення ціннісних орієнтирів, проблем і перспективних цілей; розвиток соціально-виробничих традицій, обрядів, ритуалів; укладання договорів, взаємних зобов'язань, використання різного роду систем відбору, компромісу та об'єднання інтересів; створення обставин і ситуацій, які спрямовують дії людей у потрібному напрямку, здійснення морального заохочення; виховання та навчання у процесі трансформації систем від жорсткої до синергетичної зростає, що сприяє ширшому залученню працівників до управління внутрішньо груповими явищами й процесами та індивідуально-особистісною поведінкою, розвитку в освітніх системах самоорганізації та самоуправління. 
Домінантні методи психологічного впливу в умовах трансформації освітніх систем

\begin{tabular}{|c|c|c|c|c|c|}
\hline 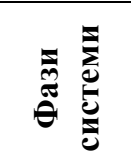 & $\begin{array}{l}\text { Жорстка } \\
\text { система }\end{array}$ & $\begin{array}{c}\text { Система } \\
\text { з делегованими } \\
\text { повноваженнями }\end{array}$ & $\begin{array}{l}\text { "М'яка" } \\
\text { система }\end{array}$ & $\begin{array}{c}\text { Система } \\
3 \text { мережевою } \\
\text { взаємодісю }\end{array}$ & $\begin{array}{c}\text { Синергетична } \\
\text { система }\end{array}$ \\
\hline \multirow{4}{*}{ 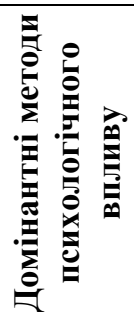 } & вимога & прохання & порада & спонукання & залучення \\
\hline & примушення & переконання & підтримка & схвалення & наслідування \\
\hline & командування & підкріплення & $\begin{array}{l}\text { похвала, } \\
\text { комплімент }\end{array}$ & навіювання & зараження \\
\hline & заборона & погашення & метод Сократа & осуд, засудження & визнання \\
\hline
\end{tabular}

Щодо економічних методів управління, то світовий досвід показує зниження їхньої ефективності в сучасних соціальних системах. Це стосується й освіти, де з огляду на галузеву специфіку, економічні методи відіграють меншу роль, ніж у виробничій сфері. Хоча варто зауважити, що в умовах трансформації освітніх систем зростання громадської складової економічних методів управління помітно підвищує їхню ефективність. Економічне планування, програмно-цільовий метод бюджетного планування, фінансове стимулювання працівників (розподіл навчального навантаження, підвищення під час атестації кваліфікаційної категорії, преміювання, виплата щорічної грошової винагороди за сумлінну працю, надбавок, необов'язкових доплат, матеріальної допомоги для вирішення соціально-побутових питань тощо), які реалізуються в кожній наступній фазі розвитку освітніх систем за зростаючої активності учасників освітнього процесу, позитивно впливають на результативність діяльності закладів освіти. Водночас, як зазначалося вище, економічні методи управління, як і організаційно-розпорядчі, з розвитком освітніх систем у значній мірі зміщуються до психологічних та соціальних методів, що сприяе ефективнішому вирішенню управлінських завдань і досягненню бажаних результатів.

Висновки та перспективи. Наведене вище дає підстави стверджувати, що в процесі розвитку освітніх систем від жорсткої до системи 3 делегованими управлінськими повноваженнями, "м'якої", 3 мережевою взаємодією і синергетичної особливостями реалізації методів управління є зростання громадської складової зазначених методів, конверсії домінантних методів управління в межах окремих груп та їхнього зміщення від організаційно-розпорядчих та економічних до психологічних і соціальних.

\section{СПИСОК ВИКОРИСТАНИХ ДЖЕРЕЛ ТА ЛІТЕРАТУРИ}

1. Теория управления : [учебник] / Под общ. ред. А. Л. Гапоненко, А. П. Панкрухина. - М. : Изд-во РАГС, 2003. $-558 \mathrm{c}$.

2. Кравченко В. О. Основи менеджменту : [навчальний посібник] / В. О. Кравченко. - Одеса : Атлант, 2012 р. $211 \mathrm{c}$.

3. Орбан-Лембрик Л. Е. Психологія управління : [посібник] / Л. Е. Орбан-Лембрик. - К. : Академвидав, 2003. $568 \mathrm{c}$.

4. Шатун В. Т. Основи менеджменту : [навчальний посібник] / В. Т. Шатун. - Миколаїв : Вид-во МДГУ ім. Петра Могили, 2006. - 376 с.

5. Пастовенський О. В. Синергетичний сценарій розвитку ефективних освітніх систем / О. В. Пастовенський // Вісник Житомирського державного університету імені Івана Франка. - 2016. - Вип. 2 (84). - С. 102-106.

6. Пастовенський О. В. Еволюція управлінського циклу в умовах розвитку освітніх систем/ О. В. Пастовенський // Вісник Житомирського державного університету імені Івана Франка. - 2017. Вип. 5(91). - С. 77-82.

\section{REFERENCES (TRANSLATED \& TRANSLITERATED)}

1. Teoriia upravleniia [Management Theory] : [uchebnyk] / Pod obshch. red. A. L. Haponenko, A. P. Pankrukhyna. M. : Izd-vo RAHS, 2003. $-558 \mathrm{~s}$.

2. Kravchenko V. O. Osnovy menedzhmentu [Basis of Management] : [navchal'nyi posibnyk] / V. O. Kravchenko. Odesa : Atlant, 2012 r. $-211 \mathrm{~s}$.

3. Orban-Lembryk L. E. Psykholohiia upravlinnia [Psychology of Management] : [posibnyk] / L. E. Orban-Lembryk. K. : Akademvydav, 2003. $-568 \mathrm{~s}$.

4. Shatun V. T. Osnovy menedzhmentu [Basis of Management] : [navchal'nyi posibnyk] / V. T. Shatun. - Mykolaiv : Vyd-vo MDHU im. Petra Mohyly, 2006. - 376 s.

5. Pastovenskyi O. V. Synerhetychnyi stsenarii rozvytku efektyvnykh osvitnikh system [Synergetic Scenario of the Development of Effective Educational Systems]/ O. V. Pastovenskyi // Visnyk Zhytomyrskoho derzhavnoho universytetu imeni Ivana Franka [Zhytomyr Ivan Franko State University Journal]. - 2016. - Vyp. 2 (84). - S. 102106. 
6. Pastovenskyi O. V. Evoliutsiia upravlins'koho tsyklu v umovakh rozvytku osvitnikh system [Evolution of the Control Cycle in the Conditions of the Development of Educational Systems] / O. V. Pastovenskyi // Visnyk Zhytomyrskoho derzhavnoho universytetu imeni Ivana Franka [Zhytomyr Ivan Franko State University Journal]. 2017. - Vyp. 5 (91). - S. 77-82.

\section{Пастовенский А. В. Особенности реализации методов управления образованием в условиях} развития образовательных систем.

В статье исследованы особенности реализаџии методов управления образованием в условиях развития образовательных систем. Сделан вывод, что в процессе эволюичи образовательных систем от жесткой к системе с делегированными управленческими полномочиями, "мягкой", с сетевым взаимодействием и синергетической особенностями реализации методов управления является рост общественной составляющей указанных методов, конверсия доминантных методов управления в пределах отдельных групп и их смещение от организационно-распорядительных и экономических к психологическим и социильным.

Ключевые слова: развитие, образовательная система, доминантные методы управления, общественная составляющая, конверсия, смещение.

\section{Pastovenskyi O. V. The Peculiarities of Educational Management Methods Implementation in the Conditions of Educational Systems Development.}

The peculiarities of educational management methods implementation in the conditions of educational systems development are investigated in the article.

The analysis is carried out on the example of the methods determined by the traditional classification, among which are the organizational, administrative, social, psychological and economic ones.

It is proved that one of the peculiarities of the implementation of management methods is the growth of their social component: in the rigid educational system these methods are implemented on the basis of taking into account the positions of the administration, whereas in the system with delegated management powers this process is realized due to taking into account the opinion of the management and leaders of social subgroups; in the "soft" system this process is implemented on the basis of coordination of their positions; in the system with network interaction the mentioned process is realized though taking into account the opinion of the participants of the educational process; at last in the synergetic system this process is based on the coordination of the positions of the latter.

The ways of dominant methods of management conversion in the groups of administrative methods and the methods of psychological influence are considered.

It is emphasized that in modern educational systems the role of organizational-administrative and economic methods is reduced.

It is concluded that in the process of developing educational systems the peculiarities of implementation of mentioned management methods are the growth of the public component of these methods, as well as the conversion of dominant management methods within individual groups and their shift from organizationaladministrative and economic to psychological and social ones.

Key words: development, educational system, dominant management methods, public component, conversion, shift. 